\title{
Short-term effects of single-tree selection cutting on stand structure and tree species composition in Valdivian rainforests of Chile
}

\author{
Florian Schnabel ${ }^{1 *}$ (D, Pablo J. Donoso ${ }^{2}$ and Carolin Winter $^{3}$ (I)
}

\begin{abstract}
Background: The Valdivian temperate rainforest, one of the world's 25 biodiversity hotspots, is under a continued process of degradation through mismanagement. An approach to reverse this situation might be the development of uneven-aged silviculture, combining biodiversity conservation and timber production.

Methods: We examined the short-term effects of single-tree selection cutting on stand structure and tree species (richness, diversity and composition) in the Llancahue Experimental Forest in south-central Chile to quantify changes in comparison with old-growth rainforests of the evergreen forest type. We compared plots with high and low residual basal areas ( 60 and $40 \mathrm{~m}^{2} \mathrm{ha}^{-1}$ ) and a control old-growth forest.

Results: Both cutting regimes achieved a balanced structure with reverse-J diameter distribution, continuous forest cover and sufficient small-sized trees. Compared to the old-growth forest, there were no significant changes in tree species richness and diversity. The only shortcomings detected were significant reductions in diameter and height complexity as assessed by the Gini coefficient, Shannon $\mathrm{H}^{\prime}$ and standard deviation, with a significantly lower number of large-sized trees (dbh $50 \mathrm{~cm}+$, height $23 \mathrm{m+}$ ), especially in the low residual basal area regime.

Conclusions: We suggest the intentional retention of a certain number of large-sized and emergent trees as strategy for biodiversity conservation. If adjusted accordingly, single-tree selection is a promising approach to retain many old-growth attributes of the Valdivian rainforest in managed stands while providing timber for landowners.
\end{abstract}

Keywords: Uneven-aged silviculture, Old-growth forest attributes, Biodiversity, Evergreen forest type, Sustainable forest management, Temperate rainforests

\section{Background}

The Chilean evergreen rainforest in the Valdivian Rainforest Ecoregion $\left(35-48^{\circ} \mathrm{S}\right)$ is a unique, but endangered, ecosystem. It is one of the world's 25 biodiversity hotspots due to its abundance of vascular plant and vertebrate species and high degree of endemism, as well as a conservation priority due to it undergoing exceptional loss of habitat (Myers et al. 2000; Olson and Dinerstein 1998). This loss is caused basically due to illegal logging and inappropriately conducted legal selective cutting

\footnotetext{
* Correspondence: florianschnabel@posteo.org

${ }^{1}$ Chair of Silviculture, Faculty of Environment and Natural Resources,

University of Freiburg, Tennenbacherstr. 4, 79106 Freiburg, Germany

Full list of author information is available at the end of the article
}

(cut the best and leave the worst; sensu Nyland (2002)), which destroy the multi-aged stand structure of these old-growth forests, leading to thousands of hectares of degraded forests (Moorman et al. 2013; Donoso 2013; Schütz et al. 2012; Myers et al. 2000; Olson and Dinerstein 1998). Old-growth forests of the evergreen forest type harbour the highest tree species richness in Chile and consist of a mixture of mostly shade-tolerant and moderately shade-tolerant (hereafter referred to as "midtolerant") broadleaved evergreen hardwood species and some conifers of the Podocarpaceae family (Donoso and Donoso 2007). The biodiversity associated with the structural and compositional attributes of these oldgrowth forests must not only be maintained in reserves 
(Moorman et al. 2013; Bauhus et al. 2009) but also in managed forests, combining the needs of the local population for forest products with biodiversity conservation (Moorman et al. 2013). A promising way to address this is the development of a silviculture regime that: (a) maintains forest attributes that are close to the natural state of old-growth forests; and (b) allows stakeholders to benefit from timber harvesting.

In this study, we use the term "old-growthness" to refer to the degree of the retention of old-growth structural and compositional attributes in managed stands following Bauhus et al. (2009). Old-growth forests are defined here through the presence of key structural and compositional attributes including a high number of large trees, a wide range of tree sizes, complex vertical layering, the presence of late successional tree species and large amounts of standing and lying dead wood among others (Bauhus et al. 2009; Mosseler et al. 2003). The maintenance of these attributes in managed stands is essential for sustaining forest biodiversity as has been illustrated, for example, in boreal ecosystems (Bauhus et al. 2009 and citations within). The rationale is that since natural forest ecosystems and their dynamics are able to sustain the whole range of forest-dwelling species and forest functions, silviculture that mimics natural dynamics should be a good approach for sustaining forest biodiversity (Schütz et al. 2012).

Currently in Chile, the application of single-tree selection cutting is believed to be the most promising and adequate approach for uneven-aged forests (Donoso 2013; Schütz et al. 2012; Donoso et al. 2009; Siebert 1998). Chilean native evergreen forests in south-central Chile are dominated by several commercially valuable hardwood shade-tolerant or mid-tolerant species, a major requisite to work with selection silviculture. Moreover, it has been shown that some of these species have much faster diameter growth rates under lower levels of basal area than those found in dense unmanaged old-growth forests (Donoso 2002; Donoso et al. 2009). Due to rare implementation, however, it remains unknown how the forest ecosystem is influenced through this type of silviculture and which would be the economic benefits in Chile, although preliminary estimates of timber revenues are positive (Nahuelhual et al. 2007).

Nonetheless, there is abundant evidence for other forests that selection systems can maintain a high forest cover, complex vertical layering and balanced/regulated structures while providing income through timber sales at regular intervals on a sustainable basis (e.g. O'Hara 2014; Schütz et al. 2012; Pukkala and Gadow 2012; Gronewold et al. 2010; O'Hara et al. 2007; Keeton 2006; Bagnaresi 2002). For example, forests in the European Alps can harbour high structural and vegetation diversity even after several centuries of uneven-aged management
(Bagnaresi 2002). The possible lack of old-growth attributes like large-sized trees can, however, be a concern (Bauhus et al. 2009 and citations within). Another general concern regarding selection silviculture is that through their evenly distributed small-scale disturbances, single-tree selection cutting might favour the development of shade-tolerant species at the expense of mid-tolerant ones, creating an abundant but homogenous regeneration and relatively low horizontal heterogeneity (Angers et al. 2005; Doyon et al. 2005).

These considerations should be addressed before a new silvicultural scheme is applied at a large scale to avoid unwanted side effects. In the present work, our aim was, therefore, to evaluate the impacts of single-tree selection cutting with two different residual basal areas, upon structural and compositional attributes of oldgrowth temperate rainforests of the evergreen forest type. We were interested in finding management approaches that could avoid negative impacts on oldgrowth attributes and associated biodiversity at the stand scale. The objectives were to: (a) quantify the type and magnitude of structural and compositional changes induced through single-tree selection cutting with high residual basal areas (HRBA; $60 \mathrm{~m}^{2} \mathrm{ha}^{-1}$ ) and low residual basal areas (LRBA; $40 \mathrm{~m}^{2} \mathrm{ha}^{-1}$ ); and (b) identify key structural and compositional attributes of oldgrowthness that were affected through single-tree selection cutting with HRBA and LRBA. Unmanaged and well-conserved forests of the evergreen forest type in Chile reach $80-100 \mathrm{~m}^{2} \mathrm{ha}^{-1}$ in basal area and support regeneration of almost exclusively shade-tolerant species (Donoso and Nyland 2005). The rationale for these two levels of residual basal areas was, therefore, that singletree selection with LRBA would create relatively more light availability and was expected to favour the development of both ecologically and economically important mid-tolerant tree species (Donoso 2013). However, there might be trade-offs in terms of greater structural and compositional changes at LRBA compared with HRBA.

\section{Methods}

\section{Study area and experimental design}

The study was conducted in the Llancahue watershed $\left(39^{\circ} 50^{\prime} 20^{\prime \prime}\right.$ south and $73^{\circ} 07^{\prime} 18^{\prime \prime}$ west) in the intermediate depression of south-central Chile, a 1270-ha state-owned reserve that is administered by the University Austral de Chile (UACh) (Fig. 1).

The low-elevation forest of the study area corresponds to the evergreen forest type, more specifically to the subtype dominated by shade tolerant species with few emergent Nothofagus trees, according to the official classification in Chile, and is part of the Valdivian Rainforest Ecoregion (Donoso and Donoso 2007). Llancahue lies between 50 and $410 \mathrm{~m}$ a.s.l., receives $2100 \mathrm{~mm}$ 


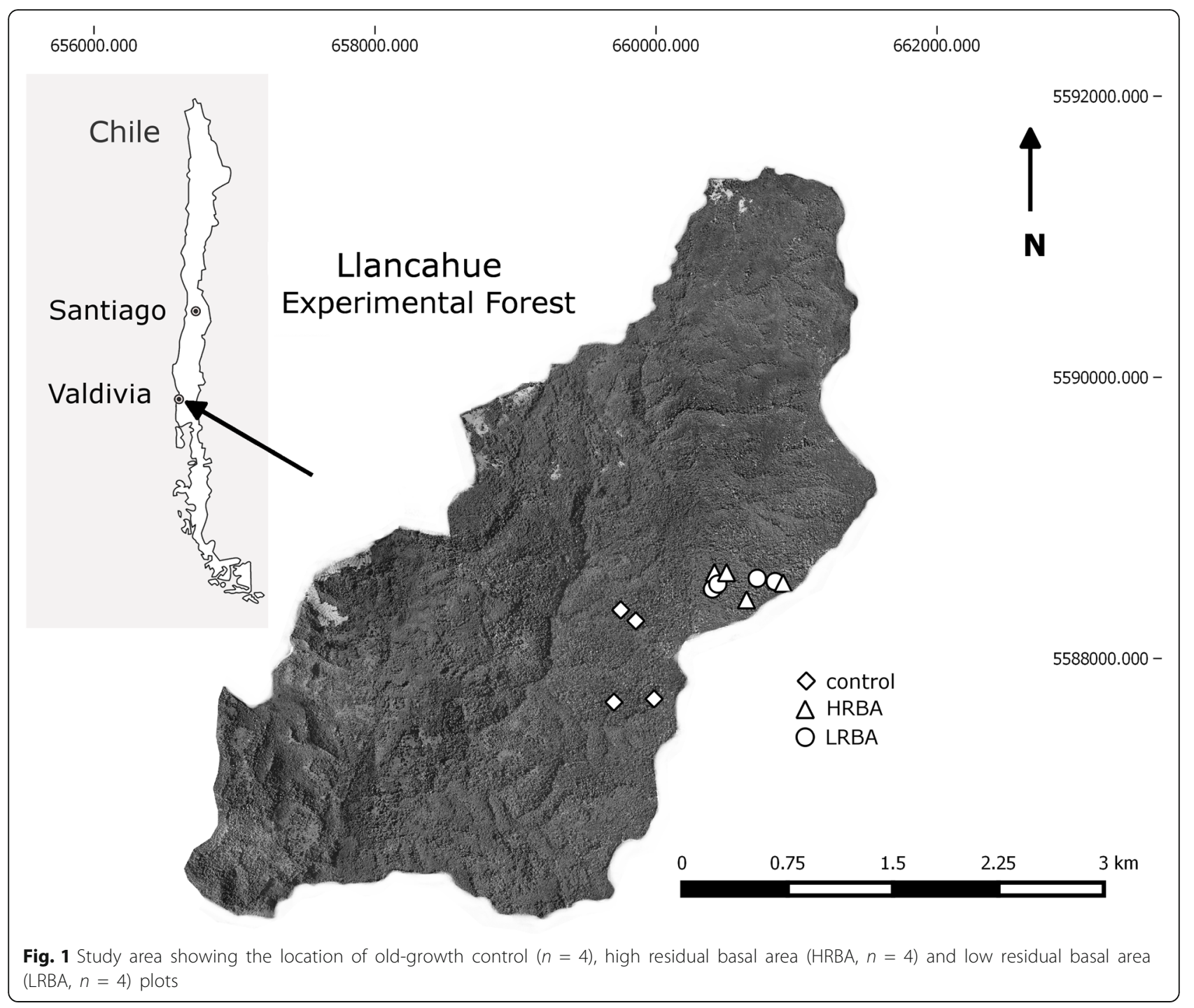

average annual rainfall and has an average annual temperature of $12.2{ }^{\circ} \mathrm{C}$ (Oyarzún et al. 2005; Fuenzalida 1971). Stands dominated by the shade-tolerant species Aextoxicon punctatum R. et Pav. and Laureliopsis philippiana (Looser) Schodde and the midtolerant species Eucryphia cordifolia Cav. and Drimys winteri J.R. et G. Forster were chosen. All stands had an uneven-aged structure and basal areas characteristic for this forest type. In the intermediate depression of south-central Chile, nearly all remnant old-growth forests show signs of illegal selective cuttings, especially since the twentieth century (Donoso and Lara 1995) and at low elevations. Signs include large stumps of few valuable species and increased cover of Chusquea spp., especially at low residual densities. This is also the case for stands selected in this study, which show signs of past harvests of a few large trees over the last three decades.
The experimental design consisted of eight plots $2000 \mathrm{~m}^{2}(50 \times 40 \mathrm{~m})$ each, which were subjected to single-tree selection cutting in 2012 and were reevaluated two growing seasons afterwards in 2014. Four plots were cut to achieve a residual basal area of $60 \mathrm{~m}^{2} \mathrm{ha}^{-1}$ and four plots to $40 \mathrm{~m}^{2} \mathrm{ha}^{-1}$, called high and low residual basal area (HRBA and LRBA), respectively (Table 1). The BDq method proposed by Guldin (1991) with a maximum diameter of $80 \mathrm{~cm}$ and a $q$ factor (the difference between successive diameter classes) of 1.3 in average for a balanced diameter distribution was used based on recommendations in Schütz et al. (2012). Since this was the first time the stands were cut following a selection system, only half of the trees above the maximum diameter were cut to avoid a severe change and potential damage to residual trees. The main target species of selection silviculture are A. punctatum, L. philippiana, D. winteri, E. cordifolia and Podocarpaceae 
Table 1 Basal area $\left(\mathrm{m}^{2} \mathrm{ha}^{-1}\right)$ per treatment and plot before (2012) and after the harvesting (2014)

\begin{tabular}{|c|c|c|c|c|c|c|c|c|c|}
\hline \multirow[b]{2}{*}{ Plot } & \multicolumn{2}{|c|}{ Control } & \multicolumn{4}{|c|}{ High residual basal area (HRBA) } & \multicolumn{3}{|c|}{ Low residual basal area (LRBA) } \\
\hline & & Plot & Before & After & Harvested & Plot & Before & After & harvested \\
\hline $\mathrm{C} 1$ & 83.8 & S2 & 73.3 & 59.4 & 13.9 & S1 & 50.0 & 41.3 & 8.7 \\
\hline$C 2$ & 99.2 & S4 & 93.1 & 59.9 & 33.2 & S3 & 65.2 & 41.4 & 23.8 \\
\hline C3 & 77.6 & S6 & 59.2 & 53.0 & 6.2 & S5 & 61.1 & 38.7 & 22.4 \\
\hline C4 & 85.8 & S8 & 80.2 & 60.6 & 19.6 & S7 & 74.2 & 43.4 & 30.9 \\
\hline Average & 86.6 & & 76.5 & 58.2 & 18.2 & & 62.7 & 41.2 & 21.4 \\
\hline
\end{tabular}

conifers if the expected product is timber and E. cordifolia if the objective of the harvest is firewood. For this first harvest, the rule "cut the worst, leave the best" was applied to enhance the quality and growth of the residual stock by preferentially harvesting defective and unhealthy trees. This approach contrasts with current selective cuttings that are used under the Chilean law, which do not control for residual stand structure, allow the harvest of $35 \%$ of the basal area per hectare in 5year cutting cycles and preferably cut the most valuable trees instead of the worst (Donoso 2013; Schütz et al. 2012).

Four permanent plots $900 \mathrm{~m}^{2}(30 \times 30 \mathrm{~m})$ each that showed only minimal signs of past illegal cuttings were used as control. Although smaller than the cut plots, plot sampling sizes for temperate old-growth forests have been traditionally considered adequate with at least $500 \mathrm{~m}^{2}$ in Chile (Prodan et al. 1997) and elsewhere (Lombardi et al. 2015), so the plots used in this study provide a reliable sampling of the variables tested. Moreover, different plot sizes were addressed through choosing analysis methods that allow for unbiased testing of different sample sizes (see below).

In Chile, the cutting intensity for the evergreen forest type is restricted to an average maximum of $35 \%$ of the original basal area (Donoso 2013). To achieve two levels of residual basal areas (HRBA and LRBA), while at the same time complying with the legal restrictions, we had to choose plots with the lowest initial basal areas for LRBA (average 34\% of the basal area cut) and those with the largest basal areas for HRBA (average 24\% of the basal area cut) (Table 1). Final average residual basal areas were $58.2 \mathrm{~m}^{2} \mathrm{ha}^{-1}$ for HRBA plots and $41.2 \mathrm{~m}^{2}$ ha ${ }^{-1}$ for LRBA plots (Table 1). The plot where the least trees were cut was number S6 (10.5\%), and the one with the most trees cut was S7 (41.6\%). Apart from these extremes, plots had a cutting intensity that ranged between 17 and $37 \%$ of the original basal area.

We acknowledge differences in the original basal areas of the three groups of plots selected for this study (oldgrowth, HRBA and LRBA). However, to reach the expected residual basal areas proposed by Donoso (2002) for uneven-aged silviculture in Chilean forests, within legal restrictions, we had to choose these partially cut stands that are common in the landscape. From there, rather than from pristine old-growth forests, we sought to find out how selection stands do, or do not, maintain old-growth attributes.

\section{Sampling design and data collection}

Three parameters for quantifying structural and compositional attributes were used in this study that have been largely and successfully applied in other ecosystems (e.g. Gadow et al. 2012; Lexerød and Eid 2006; McElhinny et al. 2005): (a) diameter at breast height (dbh) measured at $1.3 \mathrm{~m}$; (b) tree height; and (c) tree species. All trees with a dbh $\geq 5 \mathrm{~cm}$ were recorded by species and diameter for the eight plots before cutting (2012) and were re-evaluated two growing seasons after harvesting (2014). The four control plots were measured once in 2014. Tree height was included as an additional and more direct measurement of vertical complexity only in 2014. Tree height was measured for all trees with $\mathrm{dbh} \geq 10 \mathrm{~cm}$ with a Vertex III hypsometer.

To quantify tree size complexity, three diversity indices were used to analyse the diameter and height data of the trees: (a) standard deviation; (b) Gini coefficient (Lexerød and Eid 2006; Gini 1912); and (c) ln-based Shannon index $\left(H^{\prime}\right)$ (Lexerød and Eid 2006; Shannon 1948). Standard deviation has been widely used as a way to calculate diameter and height complexity and can be compared with more complex indices for stand structural comparisons (McElhinny et al. 2005 and citations within). The Gini coefficient has also been used successfully to describe structural changes. For example, Lexerød and Eid (2006) found that the Gini coefficient was superior in discriminating between stands and was considered to have a very low sensitivity to sample size in a comparison of eight diameter diversity indices. It is calculated with the following equation:

$$
\mathrm{GC}=\frac{\sum_{j=i}^{n}\left(2_{j}-n-1\right) \mathrm{ba}_{j}}{\left.\sum_{j=i}^{n} \mathrm{ba}_{j}(n-1)-1\right)}
$$

where $b a$ stands for the basal area of tree $j\left(\mathrm{~m}^{2} \mathrm{ha}^{-1}\right)$.

Finally, the Shannon index is a widely used measure of tree size complexity for diameter distributions, which allows a direct comparison of different distributions through 
one single value (e.g. Lexerød and Eid 2006; McElhinny et al. 2005; Wikström and Eriksson 2000). It is calculated after the following equation:

$$
H^{\prime}=-\sum_{i=1}^{S} P_{i} \ln \left(P_{i}\right)
$$

where $P$ stands for the proportion of number of trees in size class $i$ or per species $i$ and $S$, for the number of dbh classes or species.

An important quality of the Shannon index and the Gini coefficient is their independence of stand density as proven for example by Lexerød and Eid (2006). These indices were used: (a) due to their abilities documented in the literature (especially independence of sample size); and (b) to have a more robust result than using only one index. The standard deviation and the Gini coefficient were calculated from original individual tree data while the Shannon index was calculated on the basis of $5-\mathrm{cm}$ diameter classes as suggested by Lexerød and Eid (2006). All three indices have been used similarly to describe diameter complexity as well as height complexity (Lexerød and Eid 2006). The values of the Gini coefficient range from $(0,1)$, with 1 standing for total inequality, while the Shannon index values range from $(0, \ln (S))$ (Lexerød and Eid 2006). The standard deviation ranges from $[0, \infty]$. For all three indices, a higher index value reflects a wider range of tree diameters and heights and consequently greater complexity (Lexerød and Eid 2006). Index values were calculated for each plot and then compared between treatments to quantify the changes in structural complexity after management. To quantify a potential loss of large and/or emergent trees in more detail than with the complexity indices, trees were grouped in five diameter classes and five height strata based on diameter and height ranges known for these forests (Table 2).

Tree species richness was assessed using rarefaction, a statistical method to repeatedly re-sample richness out of a random pool of samples constructed out of the field data (e.g. different plots). This allowed an unbiased comparison of richness among different plot sizes (Kindt and Coe 2005). The rarefaction curve represents the average

Table 2 Diameter (dbh) classes and height strata used to compare plots in this study

\begin{tabular}{llll}
\hline Diameter class & Range $(\mathrm{cm})$ & Height stratum & Range $(\mathrm{m})$ \\
\hline Very small & $5-9.9$ & Low understorey & $0-9.9$ \\
Small & $10-24.9$ & Upper understorey & $10-14.9$ \\
Intermediate & $25-49.9$ & Low canopy & $15-22.9$ \\
Large & $50-99.9$ & Upper canopy & $23-29.9$ \\
Very large & $100+$ & Emergent & $30+$ \\
\hline
\end{tabular}

richness of a treatment at a given number of sampled area.

Species diversity and evenness per treatment were calculated for each plot using the ln-based Shannon index $\left(H^{\prime}\right)$ (Eq. 2) and evenness using Pielou's evenness index $\left(J^{\prime}\right)$ as proposed by several authors (e.g. Alberdi et al. 2010; Kern et al. 2006). The value of J' was calculated as $H^{\prime} / \ln (S)$ where $H$ is the Shannon diversity index and $S$, the species richness. Species diversity indices are dependent on sample size (Kindt and Coe 2005) so they were calculated only for the plots with selection cutting. This was done to avoid a biased comparison of species diversity due to the different sample sizes between treated and untreated plots.

To assess changes in species composition in more detail, the number of trees per species was calculated for each plot and then compared between treatments. Furthermore, the importance value (IV; Eq. 3) of each species was calculated as the sum of its relative density $(\mathrm{RD})$, relative dominance (Rd) and relative frequency $(\mathrm{RF})$ where density $(D)$ is the number of individuals per hectare, dominance $(d)$ is the basal area (BA) of each species per hectare and frequency $(F)$ is the number of plots where a species is present divided by the total number of plots (de Iongh Arbainsyah et al. 2014; Mueller-Dombois and Ellenberg 1974).

$$
\mathrm{IV}(\text { Importance Value })=(\mathrm{RD}+\mathrm{Rd}+\mathrm{RF}) / 3
$$

\section{Statistical analysis}

Index data as well as the number of trees in the diameter and height classes were compared between the different years of observation (pre/post harvesting) and among treatments (control/HRBA/LRBA). Index data was analysed using linear mixed models (LMM) and generalised least square models (GLS). For the number of trees, generalised linear mixed models (GLMM) and generalised linear models (GLM) with Poisson distribution were used, since the data correspond to counts of individuals. Overdispersion was tested and, if found, a quasi-GLM model was used with a variance of $\varnothing \times \mu$ with $\varnothing$ as dispersion parameter and $\mu$ as mean, as suggested by Zuur et al. (2009).

The effect of harvesting was determined using year and treatment as fixed effects. The difference between years was analysed through comparing the treatments with selection cutting, without incorporating the control. For this analysis, plots were incorporated as random effect since repeated measurements were used in this study, thus using LMM or GLMM for this analysis. The differences among the three treatments were analysed before and after the harvesting by GLS and GLM using management as fixed effect. The assumptions of 
normality and heterogeneity of variance were tested through examining the model residuals and the ShapiroWilk test for normality. If heterogeneity of variance was found, the variance function (varIdent) was used to model heteroscedasticity to avoid transformations. Models with and without variance functions were compared through the information criteria AIC and the model presenting the lowest AIC was chosen. All statistical analysis was conducted using R 3.1 (R Core Team 2014), the $R$ packages nlme (Pinheiro et al. 2014), vegan (Oksanen et al. 2014), BiodiversityR (Kindt and Coe 2005) and AER (Kleiber and Zeileis 2008) as well as the software InfoStat (DiRienzo et al. 2011).

\section{Results}

\section{Diameter distribution}

The control plots showed a reverse-J diameter distribution with a slight trend to a rotated-sigmoid distribution, due to a relatively high number of large trees between 50 and $100 \mathrm{~cm}$ dbh (Fig. 2). The HRBA and LRBA plots showed a reverse-J diameter distribution before and after the application of single-tree selection cutting (Fig. 2).

In comparison to the control plots, treated plots had around twice as many young trees between 5 and $15 \mathrm{~cm}$ dbh (Fig. 2) before and after harvesting. For emergent trees $(100+\mathrm{cm} \mathrm{dbh})$, a clear trend existed, with most trees in this diameter class in the control plots (max. diameter $160 \mathrm{~cm}$ ) and few in the LRBA plots (max. diameter $105 \mathrm{~cm}$ ). The LRBA plots had already fewer emergent trees before harvesting (plots had been slightly subjected to "selective" cuts in the past as mentioned above) but the difference became more pronounced after single-tree selection cutting. Additionally, selection cutting reduced the number of large trees $(50-100 \mathrm{~cm}$ dbh), especially in the LRBA plots (Fig. 2).

\section{Structural complexity indices}

Harvesting significantly reduced diameter complexity as assessed by the Gini coefficient ( $p=0.0012)$, the Shannon index $(p=0.0039)$ and the standard deviation $(p=0.0002)$ (Table 3). Moreover, all three indices provided a logical and consistent ranking of diameter complexity, with the highest index values in the control, followed by the HRBA and then by the LRBA plots after harvesting (Table 3).

The Gini coefficient for diameter complexity was not significantly different between control and treated plots, while the Shannon index had already significantly higher values in the control plots before harvesting (see asterisks, Table 3). The significance of this difference became

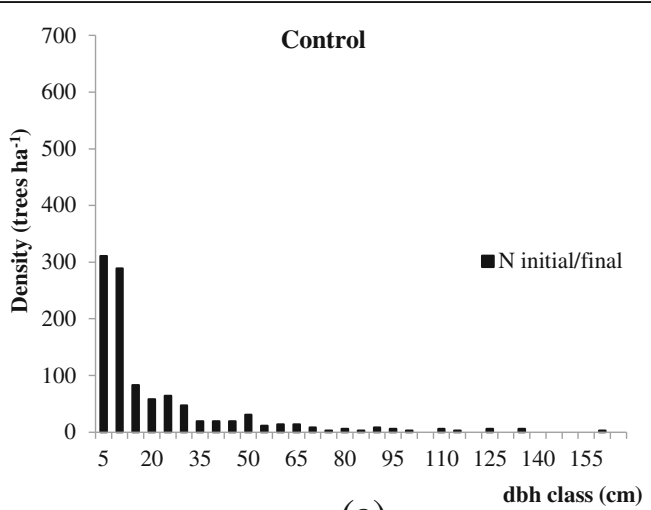

(a)
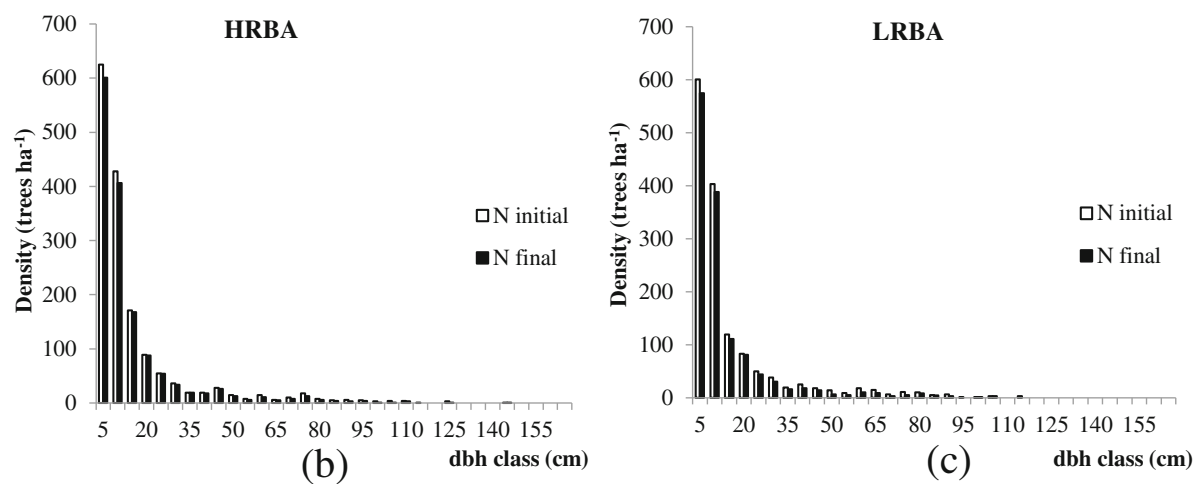

Fig. 2 Observed diameter distributions of $\mathbf{a}$ the old-growth control, $\mathbf{b}$ high residual basal area (HRBA) and $\mathbf{c}$ low residual basal area (LRBA). The histograms represent the average number of trees per hectare per treatment (four plots each) before and after harvesting 
Table 3 Mean values for the Gini coefficient, the Shannon index and the standard deviation for diameter at breast height (dbh) and height data and for the Shannon index and the evenness index for species diversity before and after harvesting. Values are expressed as mean \pm 1 standard deviation. Significant treatment differences with the control are shown with asterisks after the index value, with ${ }^{*} p=0.05-0.01,{ }^{* *} p=0.01-0.001$ and ${ }^{* * *} p=<0.001$, respectively. Significant harvesting impacts are mentioned in the text

\begin{tabular}{|c|c|c|c|c|c|}
\hline & \multirow[t]{2}{*}{ Control } & \multicolumn{2}{|c|}{ High residual basal area (HRBA) } & \multicolumn{2}{|c|}{ Low residual basal area (LRBA) } \\
\hline & & Before & After & Before & After \\
\hline \multicolumn{6}{|l|}{ Diameter complexity } \\
\hline Gini coefficient & $0.814 \pm 0.020$ & $0.811 \pm 0.040$ & $0.801 \pm 0.041$ & $0.804 \pm 0.021$ & $0.789 \pm 0.020$ \\
\hline Shannon index & $2.051 \pm 0.147$ & $1.833 \pm 0.069^{*}$ & $1.773 \pm 0.068^{* *}$ & $1.793 \pm 0.038^{* *}$ & $1.655 \pm 0.102^{* * *}$ \\
\hline Standard deviation & $25.085 \pm 3.867$ & $19.001 \pm 4.354^{*}$ & $16.762 \pm 2.834^{* *}$ & $17.438 \pm 1.696^{*}$ & $14.499 \pm 1.036^{* * *}$ \\
\hline \multicolumn{6}{|l|}{ Height complexity } \\
\hline Gini coefficient & $0.214 \pm 0.026$ & - & $0.198 \pm 0.028$ & - & $0.207 \pm 0.017$ \\
\hline Shannon index & $1.747 \pm 0.172$ & - & $1.458 \pm 0.185^{*}$ & - & $1.457 \pm 0.093^{*}$ \\
\hline Standard deviation & $7.973 \pm 1.233$ & - & $5.739 \pm 1.378^{*}$ & - & $5.846 \pm 0.549^{*}$ \\
\hline \multicolumn{6}{|l|}{ Tree species diversity } \\
\hline Shannon index & - & $1.888 \pm 0.177$ & $1.869 \pm 0.206$ & $1.979 \pm 0.342$ & $1.975 \pm 0.316$ \\
\hline Evenness index & - & $0.725 \pm 0.043$ & $0.717 \pm 0.046$ & $0.767 \pm 0.070$ & $0.765 \pm 0.066$ \\
\hline
\end{tabular}

more pronounced for both HRBA and LRBA plots through harvesting (Table 3). The standard deviation showed the same pattern as the Shannon index (Table 3). Before harvesting, control plots had already a significantly higher complexity than the treated plots, but these differences were only slightly significant (Table 3). After harvesting, these differences became highly significant for both HRBA and LRBA plots.

The Gini coefficient of height complexity showed no significant difference between the untreated and treated plots (Table 3). The Shannon index showed a significantly higher height complexity after harvesting in the unmanaged plots than in the managed ones. The same was observed for the standard deviation, which was significantly higher in the control plots. No clear differences in height complexity existed between the HRBA and LRBA plots.

\section{Diameter classes and height strata}

Small-sized trees, small diameter classes (very small and small) and low height strata (low understorey and upper understorey) were more abundant in the treated plots than in the control plots before harvesting (Table 4). In regard to diameter classes, harvesting reduced the number of small-sized trees only marginally, leaving an abundant residual growing stock. On the contrary, intermediate- to very large-sized trees $(\mathrm{dbh} 25 \mathrm{~cm}+$, height $23 \mathrm{~m}+$ ) were strongly influenced by harvesting. The density of trees with an intermediate diameter was already significantly higher in the control compared to the LRBA plots before harvesting (see asterisks, Table 4). Harvesting significantly $(p=0.0011)$ reduced their number, leading to a significantly higher number of trees in the intermediate diameter class in the control compared to selection plots, with a more pronounced difference for the LRBA plots after harvesting (Table 4).

The number of large diameter trees was nearly the same for control, HRBA and LRBA plots before harvesting (Table 4). Harvesting significantly reduced their density $(p<0.0001)$, resulting in a significantly higher number of large diameter trees in the control compared to the LRBA but not to HRBA plots (Table 4). The number of very large diameter trees was highest in the control already before harvesting, but without significant differences due to the high variability between plots (Table 4). Harvesting significantly reduced their number $(p<0.0001)$, resulting in a significantly higher tree density of these trees in the control compared to LRBA plots (Table 4). No significant differences could be found between control and HRBA plots (Table 4). The HRBA plots had a higher number of intermediate to very large diameter trees than their LRBA counterparts (Table 4).

In regard to height classes, no significant difference was found for the number of low canopy trees, while upper canopy trees were significantly more abundant in the control than in the treated plots (Table 4). The difference between untreated and treated plots was even more pronounced for emergent trees with significantly more emergent trees in the control $\left(72\right.$ trees $\left.\mathrm{ha}^{-1}\right)$ compared to HRBA (19 trees ha ${ }^{-1}$ ) and LRBA (10 trees ha ${ }^{-1}$ ) plots after harvesting (Table 4).

\section{Tree species richness and diversity}

Tree species richness was not changed as a result of harvesting. Thus, only the results after harvesting are 
Table 4 Mean number of trees per hectare per diameter class (trees $\mathrm{dbh} \geq 5 \mathrm{~cm}$ ) and height strata (trees $\mathrm{dbh} \geq 10 \mathrm{~cm}$ ) before and after harvesting. Diameter classes and height strata are explained in Table 3. Values are expressed as mean \pm 1 standard deviation. Significant treatment differences with the control are shown through an asterisk after the mean number of trees, with ${ }^{*} p=0.05-$ $0.01,{ }^{* *} p=0.01-0.001$ and ${ }^{* * *} p \leq 0.001$, respectively. Significant harvesting impacts are mentioned in the text

\begin{tabular}{|c|c|c|c|c|c|}
\hline & \multirow[t]{2}{*}{ Control } & \multicolumn{2}{|c|}{ High residual basal area (HRBA) } & \multicolumn{2}{|c|}{ Low residual basal area (LRBA) } \\
\hline & & Before & After & Before & After \\
\hline \multicolumn{6}{|l|}{ Diameter class } \\
\hline Total & $1039 \pm 252$ & $1579 \pm 301^{*}$ & $1491 \pm 295^{*}$ & $1455 \pm 202^{*}$ & $1331 \pm 190$ \\
\hline Very small & $494 \pm 166$ & $895 \pm 167^{* *}$ & $861 \pm 164^{*}$ & $849 \pm 140^{*}$ & $818 \pm 156^{*}$ \\
\hline Small & $258 \pm 115$ & $446 \pm 141^{*}$ & $429 \pm 130$ & $384 \pm 50$ & $363 \pm 53$ \\
\hline Intermediate & $175 \pm 29$ & $134 \pm 31$ & $126 \pm 27^{*}$ & $130 \pm 11^{*}$ & $101 \pm 18^{* *}$ \\
\hline Large & $89 \pm 33$ & $90 \pm 27$ & $68 \pm 14$ & $88 \pm 41$ & $48 \pm 12^{*}$ \\
\hline Very large & $22 \pm 13$ & $14 \pm 15$ & $8 \pm 6$ & $5 \pm 4$ & $3 \pm 3^{*}$ \\
\hline \multicolumn{6}{|l|}{ Height stratum } \\
\hline Total & $533 \pm 137$ & - & $624 \pm 141$ & - & $510 \pm 58$ \\
\hline Low understorey & $42 \pm 32$ & - & $84 \pm 43$ & - & $75 \pm 35$ \\
\hline Upper understorey & $114 \pm 62$ & - & $271 \pm 90^{*}$ & - & $211 \pm 35$ \\
\hline Low canopy & $172 \pm 72$ & - & $195 \pm 75$ & - & $159 \pm 52$ \\
\hline Upper canopy & $136 \pm 36$ & - & $55 \pm 21^{* *}$ & - & $55 \pm 12^{* *}$ \\
\hline Emergent & $72 \pm 39$ & - & $19 \pm 22^{*}$ & - & $10 \pm 8^{*}$ \\
\hline
\end{tabular}

presented here. The confidence intervals of the three rarefaction curves overlap at the total sampled area of the control plots (Fig. 3), reflecting that tree species richness was not significantly different between unmanaged and managed plots.

Tree species diversity, as evaluated through the Shannon index, did not significantly change after harvesting (comp. Table 3). Also, no significant differences in tree species diversity existed between treated and untreated plots (comp. Table 3). The same was observed for tree species evenness which was not significantly changed through harvesting and was not different between treated and untreated plots (comp. Table 3).

\section{Tree species composition}

In general, treated and untreated plots showed a similar species composition regarding dominant tree species, as evaluated through the average number of trees per species and the importance value (IV) of each species before harvesting (Table 5). The shade-tolerant species A. punctatum and Myrceugenia planipes ( $\mathrm{H}$ et A.) Berg, however, had far higher IVs in the control plots compared

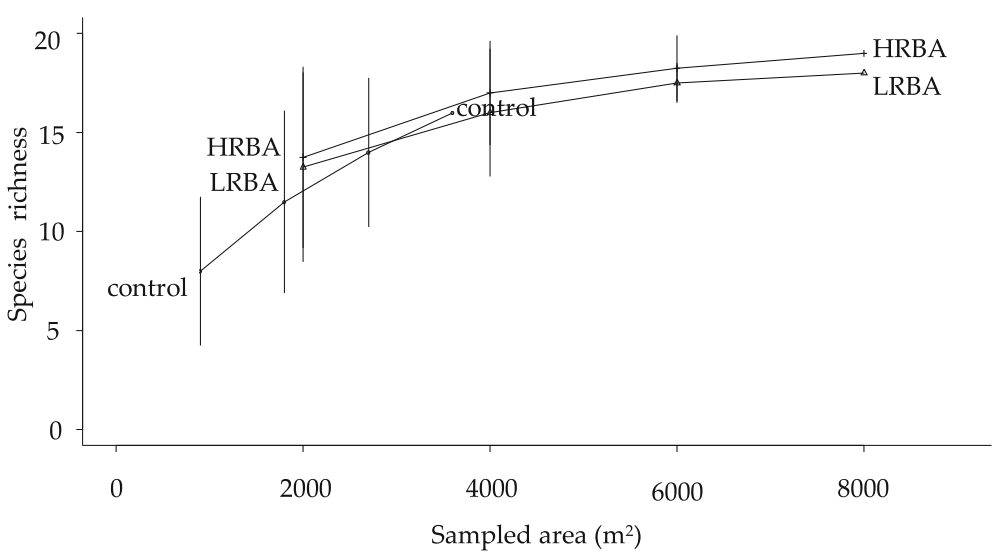

Fig. 3 Species rarefaction curves showing the mean tree species richness per sampled area for the control, high and low residual basal area (HRBA and LRBA) plots after harvesting. The rarefaction curves were calculated through repeatedly re-sampling richness out of a random pool of samples constructed out of the four sampled plots 
Table 5 Average number of trees per hectare and importance value (IV) in \% per treatment and species in 2012 and 2014

\begin{tabular}{|c|c|c|c|c|c|c|c|c|c|c|c|c|}
\hline \multirow[b]{3}{*}{ Tree species } & \multicolumn{2}{|c|}{ Control } & \multirow[b]{3}{*}{ Tree species } & \multicolumn{4}{|c|}{ High residual basal area (HRBA) } & \multirow[b]{3}{*}{ Tree species } & \multicolumn{4}{|c|}{ Low Residual Basal Area (LRBA) } \\
\hline & & & & \multicolumn{2}{|l|}{ Before } & \multicolumn{2}{|l|}{ After } & & \multicolumn{2}{|l|}{ before } & \multicolumn{2}{|l|}{ after } \\
\hline & $\begin{array}{l}\mathrm{N}^{\circ} \\
\text { trees }\end{array}$ & IV & & $\begin{array}{l}\text { No. of } \\
\text { trees }\end{array}$ & IV & $\begin{array}{l}\text { No. of } \\
\text { trees }\end{array}$ & IV & & $\begin{array}{l}\text { No. of } \\
\text { trees }\end{array}$ & IV & $\begin{array}{l}\text { No. of } \\
\text { trees }\end{array}$ & IV \\
\hline $\begin{array}{l}\text { Laureliopsis } \\
\text { philippiana }\end{array}$ & 486 & 27.7 & $\begin{array}{l}\text { Laureliopsis } \\
\text { philippiana }\end{array}$ & 591 & 25.6 & 569 & 27.6 & $\begin{array}{l}\text { Laureliopsis } \\
\text { philippiana }\end{array}$ & 525 & 27.1 & 496 & 29.4 \\
\hline $\begin{array}{l}\text { Aextoxicon } \\
\text { punctatum }\end{array}$ & 200 & 18.5 & Eucryphia cordifolia & 189 & 20.9 & 153 & 16.6 & Eucryphia cordifolia & 154 & 19.3 & 105 & 14.0 \\
\hline Eucryphia cordifolia & 53 & 16.1 & $\begin{array}{l}\text { Aextoxicon } \\
\text { punctatum }\end{array}$ & 126 & 7.3 & 123 & 8.0 & Amomyrtus luma & 228 & 8.3 & 215 & 8.7 \\
\hline Myrceugenia planipes & 147 & 8.1 & Amomyrtus luma & 194 & 6.9 & 186 & 7.1 & $\begin{array}{l}\text { Aextoxicon } \\
\text { punctatum }\end{array}$ & 91 & 7.3 & 86 & 8.0 \\
\hline Laurelia sempervirens & 6 & 4.6 & Gevuina avellana & 139 & 5.9 & 136 & 6.1 & Drimys winteri & 123 & 6.5 & 120 & 7.4 \\
\hline Amomyrtus meli & 19 & 4.0 & Drimys winteri & 51 & 3.9 & 51 & 4.2 & Amomyrtus meli & 86 & 4.9 & 83 & 5.2 \\
\hline Drimys winteri & 33 & 4.0 & Amomyrtus meli & 74 & 3.8 & 74 & 4.0 & Gevuina avellana & 78 & 4.7 & 69 & 4.8 \\
\hline Gevuina avellana & 25 & 3.2 & Lomatia ferruginea & 31 & 3.1 & 24 & 3.0 & $\begin{array}{l}\text { Rhaphithamnus } \\
\text { spinosus }\end{array}$ & 49 & 3.8 & 48 & 4.0 \\
\hline Amomyrtus luma & 22 & 2.9 & Myrceugenia planipes & 54 & 3.1 & 53 & 3.1 & Lomatia ferruginea & 48 & 3.7 & 44 & 3.8 \\
\hline Nothofagus dombeyi & 8 & 2.5 & $\begin{array}{l}\text { Dasyphyllum } \\
\text { diacanthoides }\end{array}$ & 38 & 3.0 & 34 & 2.9 & $\begin{array}{l}\text { Weinmannia } \\
\text { trichosperma }\end{array}$ & 5 & 3.1 & 5 & 3.6 \\
\hline $\begin{array}{l}\text { Weinmannia } \\
\text { trichosperma }\end{array}$ & 3 & 1.8 & $\begin{array}{l}\text { Weinmannia } \\
\text { trichosperma }\end{array}$ & 5 & 2.9 & 5 & 3.2 & Lomatia dentata & 19 & 1.7 & 16 & 1.7 \\
\hline Lomatia dentata & 19 & 1.7 & $\begin{array}{l}\text { Rhaphithamnus } \\
\text { spinosus }\end{array}$ & 19 & 2.8 & 18 & 2.9 & $\begin{array}{l}\text { Dasyphyllum } \\
\text { diacanthoides }\end{array}$ & 11 & 1.7 & 9 & 1.6 \\
\hline $\begin{array}{l}\text { Dasyphyllum } \\
\text { diacanthoides }\end{array}$ & 8 & 1.4 & Podocarpus salignus & 21 & 2.4 & 21 & 2.5 & Myrceugenia planipes & 16 & 1.7 & 14 & 1.7 \\
\hline Podocarpus salignus & 3 & 1.3 & Lomatia dentata & 25 & 2.4 & 24 & 2.4 & $\begin{array}{l}\text { Saxegothaea } \\
\text { conspicua }\end{array}$ & 6 & 1.7 & 5 & 1.6 \\
\hline Persea lingue & 3 & 1.2 & Nothofagus dombeyi & 11 & 2.0 & 11 & 2.4 & Podocarpus salignus & 6 & 1.4 & 6 & 1.4 \\
\hline \multirow[t]{4}{*}{ Lomatia ferruginea } & 3 & 1.1 & Podocarpus nubigena & 6 & 1.4 & 6 & 1.4 & Caldcluvia paniculata & 4 & 1.4 & 4 & 1.4 \\
\hline & & & Raukaua laetevirens & 3 & 1.3 & 3 & 1.3 & Podocarpus nubigena & 3 & 0.8 & 3 & 0.9 \\
\hline & & & Luma apiculata & 1 & 0.7 & 1 & 0.7 & Luma apiculata & 5 & 0.8 & 5 & 0.8 \\
\hline & & & Persea lingue & 1 & 0.6 & 1 & 0.6 & & & & & \\
\hline
\end{tabular}

with the treated ones (Table 5). The application of the single-tree selection cutting regime applied in this study had the strongest effect on E. cordifolia. The IV of this species decreased by $21 \%$, and $20 \%$ of individuals were removed as a result of the HRBA treatment (Table 5). The LRBA treatment had a more severe effect with the IV decreasing by $27 \%$, and $32 \%$ of individuals being removed (Table 5). The decrease in IV of E. cordifolia through management led to an increase of the IV of most other species (Table 5). The only other species that experienced a clear decline in the number of trees through harvesting was L. philippiana, but the strong loss of E. cordifolia still led to a rise in its IV. Except for E. cordifolia, LRBA management did not induce stronger changes in the tree species community as compared with HRBA management (Table 5). The selection cutting regime led only to marginal changes in the number of trees of all less frequent species, and no species were lost through harvesting (Table 5). Moreover, the extraction of dominant species led to a rise of IV of several less frequent species in the forest community (Table 5).

\section{Discussion}

Key structural attributes and biodiversity conservation We examined changes in key structural attributes such as reverse-J diameter distributions, complex vertical layering, variability of tree sizes, presence of advance regeneration and large/emergent trees as measures of oldgrowthness (Bauhus et al. 2009). Both residual basal area regimes evaluated in this study on single-tree selection cutting were found to maintain a balanced uneven-aged structure, forest cover continuity and a sufficient growing stock of small-sized trees. All plots, managed and unmanaged, were characterised by reverse-J shaped diameter distributions before and after harvesting. 
These findings are in accordance with studies in other forest types, where selection cutting maintained these structural forest attributes over decades while providing timber yields at regular intervals (e.g. Pukkala and Gadow 2012; Gronewold et al. 2010; O'Hara et al. 2007; Keeton 2006; Bagnaresi 2002). The observed reverse-J shaped distributions are typical for old-growth stands in the Valdivian Costal Range and the Valdivian Andes (Donoso 2013; Donoso 2005), showing that single-tree selection cutting is able to maintain this old-growth attribute. Still, results of this study cover only the shortterm impacts of selection cutting (2 years), and there may be lag effects with sensitive species. However, the growth model predictions of Rüger et al. (2007), which were parameterised for the evergreen forest type on Chiloé Island, Chile, suggest that single-tree selection cutting can maintain the above-mentioned forest attributes also on the long term. Moreover, balanced structures with similar crown covers for small-, intermediate- and large-sized trees allow more abundant regeneration and tree growth in the evergreen forest type in Chile than unbalanced ones (Schütz et al. 2012; Donoso and Nyland 2005; Donoso 2005).

Further considerations should be given to the fact that plots with a high residual basal area (HRBA) tend to approximate old-growth conditions more closely through maintaining higher numbers of large-sized trees and higher diameter complexity than plots with a low residual basal area (LRBA) (Tables 3 and 4). Similarly, Gronewold et al. (2010) concluded that (after a survey of 57 years in northern hardwood stands of North America managed through single-tree selection cutting) stands with high residual basal areas better approximated the natural disturbance history and diameter distributions of unmanaged uneven-aged stands, while low residual basal areas resulted in simpler and more regulated distributions. The higher number of small trees (advanced regeneration) already present before cutting compared to the control plots in our study most likely results from higher light availability, especially in the LRBA plots caused by previous illegal cuttings (as mentioned before).

The only shortcoming detected was the significant reduction and lower numbers of large-sized (dbh $50 \mathrm{~cm}+$, height $23 \mathrm{~m}+$ ) and emergent trees (height $30 \mathrm{~m}+$ ) in the treated plots (especially in LRBA ones), compared to the control plots after harvesting. This finding was supported by the significant reduction of diameter and height complexity (shown by all three indices) and significantly higher diameter and height complexity in the untreated plots (shown by the Shannon index and standard deviation) as a result of a reduction in the range of tree diameters and heights. All three structural indices have been widely used to quantify diameter and height complexity in managed and unmanaged forest stands and to a lesser extent to evaluate the impacts of single-tree selection cutting (Torras et al. 2012; O'Hara et al. 2007; Lexerød and Eid 2006; McElhinny et al. 2005; Acker et al. 1998). Similar to results of this study, Acker et al. (1998) reported higher values of the standard deviation of tree diameter in oldgrowth northern hardwood stands of North America compared to managed ones, but there are also studies that report a rise of diameter and height complexity under selection silviculture over time using the same three indices (Torras et al. 2012; O'Hara et al. 2007).

In particular, very large and emergent trees were far less numerous in the managed plots. Similarly, numerous other studies have found that stands managed through selection cutting have less large trees than comparable old-growth stands (e.g. Torras and Saura 2008; Rüger et al. 2007; Keeton 2006; Angers et al. 2005; Crow et al. 2002). Furthermore, stands with lower residual basal areas were found to present less large trees than stands with higher residual basal areas (Gronewold et al. 2010; Rüger et al. 2007). This is partly consistent with the findings of this study where only LRBA plots presented significantly lower numbers of large and very large diameter trees than the control plots.

Large-sized and emergent trees are, however, an important habitat for many forest dwelling species and communities that depend on this specific structural attribute of old-growth forests (Bauhus et al. 2009), such as cavity-dependent animal species like birds and mammals as well as bryophytes, lichens, fungi, and saproxylic beetles (Paillet et al. 2010; Bauhus et al. 2009). One specific example in the Chilean evergreen rainforest is the abundant flora of endemic epiphytic plants that depend on emergent trees (Díaz et al. 2010) and their greater frequency on trees with large diameters (Muñoz et al. 2003). Furthermore, bird species diversity in the evergreen forest type can be predicted by the presence of emergent trees, and their diversity is consequently higher in old-growth than in early or mid-successional forest stands (Díaz et al. 2005). It follows that a certain number of large-sized, especially emergent trees, in managed stands is crucial for biodiversity conservation. Although we do not deal with dead wood (i.e. snags and coarse woody debris) in this paper, preliminary results suggest that plots subjected to single-tree selection cutting have similar or even higher amounts of this key structural attribute (sensu Bauhus et al. 2009) compared to unmanaged old-growth forests (Schnabel et al., unpublished).

\section{Impacts on tree species richness, diversity and composition}

An important attribute for old-growthness is the high number of late successional tree species (Bauhus et al. 2009), i.e. shade-tolerant and emergent mid-tolerant 
ones in the evergreen forest type. Tree species richness, diversity and evenness were not changed through selection cutting in the short-term, which is in accordance with findings in northern hardwood forest in North America (Angers et al. 2005; Crow et al. 2002). It is therefore reasonable to conclude that the direct harvesting effects of single-tree selection (e.g. tree felling), as conducted in the present study, are compatible with preserving tree species richness and diversity within the evergreen forest type in the short term. If management guidelines such as those applied in this study are used, the same should also apply for future applications.

The numbers of less frequently occurring tree species were not reduced through selection cutting; a fact that further supports the conclusion that single-tree selection cutting is compatible with preserving tree species diversity. While most dominant tree species experienced no severe losses through selection cutting, a clear impact was noted for the mid-tolerant species E. cordifolia. It clearly declined in abundance and IV, although it remained the second species in IV. The reason for this was the preferential harvest of old/large, poor-quality $E$. cordifolia trees, to improve the quality of the residual stock in the first harvest. Moreover, E. cordifolia trees were mostly large individuals, since regeneration for this mid-tolerant species is generally scarce under closed forests (Escobar et al. 2006; Donoso and Nyland 2005) and was thus strongly impacted by the harvesting criteria of a maximum residual diameter of $80 \mathrm{~cm}$. In future harvests, impacts are likely to be more equally distributed, as most of the defective E. cordifolia trees would have already been harvested after this first selection cut. Also, E. cordifolia is one of the target tree species of selection silviculture due to its high economic value and expected fast growth and abundant regeneration at low residual basal areas (especially at $40 \mathrm{~m}^{2} \mathrm{ha}^{-1}$ ). In addition, retaining some emergent E. cordifolia trees is a conservation priority as this species harbours an exceptional high diversity and abundance of epiphytes, acting as key structure for biodiversity conservation and ecosystem processes like water and nutrient cycling (Díaz et al. 2010).

Finally, single-tree selection might favour both the recruitment of mid-tolerant species like E. cordifolia (Torras and Saura 2008; Angers et al. 2005) and/or shade-tolerant species (Keyser and Loftis 2013; Gronewold et al. 2010; Rüger et al. 2007) depending on the size of crown opening and consequent light availability (i.e. LRBA should induce more regeneration of midtolerant tree species like E. cordifolia). As the effects on tree regeneration in the evergreen forest type remain unknown in the field, different harvesting intensities might be currently the best option to promote the regeneration of both mid- and shade-tolerant tree species.

\section{Implications for management}

Overall, our results support the claim that single-tree selection cutting is a promising silvicultural approach for the evergreen forest type. This approach is certainly more promising than the currently supported selective harvesting guidelines of the Chilean law which do not control for a balanced residual stock and allow the harvest of 35\% of the basal area in 5-year cutting cycles, which is unsustainable (Donoso 2013; Schütz et al. 2012). In contrast, the only negative affect detected for the single-tree selection cutting regime applied in the present study was the clearly lower number of largesized and emergent trees in managed plots, a key structural attribute of old-growth forests and crucial for biodiversity conservation.

The management strategy of single-tree selection cutting would need to be adjusted by forest managers who wish to preserve some emergent and large-sized trees in stands managed through selection silviculture. The use of a maximum residual diameter, such as $80 \mathrm{~cm}$ in this study, actually impairs the preservation of large-sized trees (Keeton 2006). One possibility in this context would be the intentional retention of a still to be a specified number of large ( $>80 \mathrm{~cm}$ diameter) trees, especially emergent ones (e.g. Bauhus et al. 2009; Angers et al. 2005). We did maintain some large trees in the managed stands in this study because otherwise, basal area harvesting would have been too destructive, but our results suggest that leaving trees above a given maximum diameter must be an ongoing requirement. In particular, retaining emergent trees with crowns over the main canopy of the residual stock is beneficial as: (a) they may not impede the growth of either young or mature trees nor tree regeneration in the evergreen forest type (Donoso 2005); and (b) they are key structures for biodiversity conservation (Díaz et al. 2010). An additional possibility might be the use of diameter-guiding curves other than the reverse-J distribution curve used in the current study. For example, a rotated sigmoid distribution curve may satisfy ecological needs more closely through allocating more basal area and growing space to larger diameter classes (Keeton 2006). The HRBA plots tended to better approximate old-growth conditions than LRBA plots, in terms of higher numbers of largesized trees and higher structural complexity. However, it remains untested in the field as to which residual basal area selection cutting generates sufficient light availability to allow the regeneration of both shade-tolerant and mid-tolerant species in the evergreen forest type. Thus, using a combination of the two residual basal area regimes examined here (HRBA with $60 \mathrm{~m}^{2} \mathrm{ha}^{-1}$ and LRBA with $40 \mathrm{~m}^{2} \mathrm{ha}^{-1}$ ) might be an advisable option, which would contribute to more diverse and species-rich stands and additionally to the generation of a more 
heterogeneous forest structure on a broader scale, e.g. Angers et al. (2005).

Little is known about the required quantity and spatial distribution of retained emergent trees, which would be necessary to develop sound ecological management guidelines, like retention targets for biodiversity conservation (Bauhus et al. 2009; McElhinny et al. 2005). Due to a lack of information on this topic in Chile and in other ecosystems (e.g. Bauhus et al. 2009; McElhinny et al. 2005), this is a major challenge for uneven-aged silviculture, especially in forests of high diversity and endemism like the evergreen temperate forests of south-central Chile. A final concern in Chile (and elsewhere) is that Chusquea bamboos in the understorey may be a threat for regeneration (Donoso and Nyland 2005). These are usually lightdemanding species, so the creation of canopy openings above a certain size following selection cuts, especially if using group selection, could promote Chusquea spp. regeneration. This poses an important research challenge for selection silviculture in Chilean forests, i.e. determining adequate densities (for example expressed in basal area) that would maintain low levels of Chusquea spp. cover while allowing the forest stand to sustain good growth rates. Donoso (2002) studied uneven-aged forest with basal areas from 38 to $140 \mathrm{~m}^{2} \mathrm{ha}^{-1}$ in the lowlands of south-central Chile, and Chusquea spp. had levels of cover that ranged from 3 to $12 \%$. This result suggests that managed forest stands with residual basal areas as low as $40 \mathrm{~m}^{2} \mathrm{ha}^{-1}$ should not have major competition from Chusquea spp. upon tree regeneration.

From a management perspective, a great advantage of selection silviculture is the production of large logs for saw timber or veneer, products of high commercial value, while in the same time, logs of smaller dimensions are harvested that can be used for firewood or charcoal production (Moorman et al. 2013; Puettmann et al. 2015). Siebert (1998), Donoso (2002) and Donoso et al. (2009) have proposed target maximum diameters of $60-90 \mathrm{~cm}$ (80 $\mathrm{cm}$ in this study), which should generate high-value products. Operationally, harvesting requires skilled workers and marked stands after determining adequate marking guides according to the $\mathrm{BDq}$ or a similar technique. In addition, Donoso (2002) proposed 10-year cutting cycles for evergreen forests on productive lowelevation sites. Single-tree selection would thus especially offer landholders with small properties a variety of wood products at regular intervals (Puettmann et al. 2015).

Overall, major considerations to better conserve structural features and biodiversity of old-growth forests in managed stands, while also achieving good rates of timber productivity, could include: (a) retaining a certain number of large-sized, especially emergent trees; (b) using a diverse but relatively narrow range of residual basal areas that may support good development of relatively fast-growing and valuable mid-tolerant tree species associated to shade-tolerant ones; and (c) applying diameter distributions that allow for a greater allocation of basal area in relatively large trees. These considerations for stand variability in managed forests should be included in forest regulations, which should adapt to new knowledge generated through research.

Considering that mostly, we did not cut beyond 35\% harvested basal area, the maximum established in Chilean regulations, research in selection silviculture should also evaluate an ample range of harvesting intensities using a relatively ample range of initial and residual basal areas. This would allow a more robust information on thresholds to conserve in the best possible manner "old-growthness" (sensu Bauhus et al. (2009)) in managed forest ecosystems.

\section{Conclusions}

We examined changes in forest structure and tree species composition as well as possible detrimental effects on key attributes of old-growthness in stands managed through single-tree selection cutting. Through both harvest variants, high and low residual basal areas (HRBA and LRBA), a balanced, uneven-aged structure with reverse-J diameter distribution and forest cover were maintained. Also, a sufficient growing stock of smallsized trees was kept. Moreover, neither tree species richness, diversity and evenness, nor the presence of less frequent species were negatively affected on the short term. As the effects on tree regeneration remain unknown, using a combination of HRBA and LRBA may be advisable to support good development of relatively fastgrowing and valuable mid-tolerant tree species associated with shade-tolerant ones. The only negative effect detected was the clearly lower number of large-sized and emergent trees in managed plots (especially for LRBA), which are a key structural attribute of old-growth forests and crucial for biodiversity conservation. These results suggest that single-tree selection cutting, if adjusted to retain a certain number of large-sized and emergent trees, can serve as a possible means to preserve many old-growth structural and compositional attributes of the evergreen forest type in managed stands while harvesting timber for the landowners. Future experiments should test the effects of alternative selection cutting upon structural heterogeneity, diversity and productivity to balance the varied societal demands of ecosystem services expected from forest management.

\section{Additional file}

Additional file 1: Data of the Llancahue Experimental Forest in south-central Chile. (XLSX 427 kb) 


\section{Abbreviations}

Dbh: Diameter at breast height; GLMM: Generalised linear mixed models; GLS: Generalised least square models; HRBA: High residual basal area; IV: Importance value; LMM: Linear mixed models; LRBA: Low residual basal area

\section{Acknowledgements}

We sincerely thank Jürgen Huss for commenting and revising this manuscript during its elaboration and Simone Ciuti for the statistical support Moreover, we acknowledge the dedication of our field workers Ronald Rocco, Nicole Raimilla Fonseca and Pol Bacardit from the University Austral de Chile. Finally, we greatly appreciated the accommodations provided by the Lomas de Sol community during our stay in Llancahue. PJ Donoso acknowledges the support of FIBN-CONAF project no. 034/2011 and FONDECYT project no. 1150496

\section{Funding}

P.J. Donoso thanks FONDECYT Grant No. 1150496 and Project 034/2011 of the "Fondo de Investigación en Bosque Nativo" administered by the forest service CONAF.

\section{Availability of data and materials}

The dataset(s) supporting the conclusions of this article are included within the article (and its Additional file 1). The use of the Llancahue database (in Additional file 1) requires the authorization of the authors.

\section{Authors' contributions}

FS, the lead author, conceived and designed this experiment. He performed the experiment through planning and leading the field data collection, analysed the data and wrote most parts of the paper. PD conceived and coordinated the general single-tree selection cutting experiment, designed and supervised the management-interventions and established the plots. He advised in conceiving this experiment and in the data analysis, supervised the process of writing the paper and wrote parts himself. CW helped in taking the field data and analysed minor parts. She contributed during the whole study through revisions and wrote parts of the paper. FS and CW created figures and tables and formatted the paper. Author contribution rephrased without making a change to the content to provide better clarity of the indiviudal contributions. This change has been approved by CW and FS. All authors read and approved the final manuscript.

\section{Ethics approval and consent to participate}

Not applicable

\section{Consent for publication}

Not applicable

\section{Competing interests}

The authors declare that they have no competing interests.

\section{Publisher's Note}

Springer Nature remains neutral with regard to jurisdictional claims in published maps and institutional affiliations.

\section{Author details}

${ }^{1}$ Chair of Silviculture, Faculty of Environment and Natural Resources, University of Freiburg, Tennenbacherstr. 4, 79106 Freiburg, Germany. ${ }^{2}$ Insituto de Bosques y Sociedad, Facultad de Ciencias Forestales y Recursos Naturales, Universidad Austral de Chile, Casilla 567, Valdivia, Chile. ${ }^{3}$ Faculty of Environment and Natural Resources, University of Freiburg, Tennenbacherstr. 4, 79085 Freiburg, Germany.

Received: 5 March 2017 Accepted: 18 September 2017

Published online: 12 October 2017

\section{References}

Acker, S. A., Sabin, T. E., Ganio, L. M., \& McKee, W. A. (1998). Development of old-growth structure and timber volume growth trends in maturing Douglas-fir stands. Forest Ecology and Management, 104, 265-280. https://doi. org/10.1016/S0378-1127(97)00249-1.

Alberdi, I., Condés, S., \& Martínez-Millán, J. (2010). Review of monitoring and assessing ground vegetation biodiversity in national forest inventories.
Environmental Monitoring and Assessment, 164, 649-676. https://doi.org/10. 1007/s10661-009-0919-4

Angers, V. A., Messier, C., Beaudet, M., \& Leduc, A. (2005). Comparing composition and structure in old-growth and harvested (selection and diameter-limit cuts) northern hardwood stands in Quebec. Forest Ecology and Management, 217, 275-293. https://doi.org/10.1016/j.foreco.2005.06.008

Bagnaresi, U. (2002). Stand structure and biodiversity in mixed, uneven-aged coniferous forests in the eastern Alps. Forestry, 75, 357-364. https://doi.org/ 10.1093/forestry/75.4.357

Bauhus, J., Puettmann, K., \& Messier, C. (2009). Silviculture for old-growth attributes. Forest Ecology and Management, 258, 525-537. https://doi.org/10. 1016/j.foreco.2009.01.053

Crow, T. R., Buckley, D. S., Nauertz, E. A., \& Zasada, J. C. (2002). Effects of management on the composition and structure of northern hardwood forests in Upper Michigan. Forest Science, 48(1), 129-145.

de longh Arbainsyah, H. H., Kustiawan, W., \& de Snoo, G. R. (2014). Structure, composition and diversity of plant communities in FSC-certified, selectively logged forests of different ages compared to primary rain forest. Biodiversity and Conservation, 23, 2445-2472. https://doi.org/10.1007/s10531-014-0732-4

Díaz, I. A., Armesto, J. J., Reid, S., Sieving, K., \& Wilson, M. (2005). Linking forest structure and composition: avian diversity in successional forests of Chiloé Island, Chile. Biological Conservation, 123, 91-101. https://doi.org/10.1016/j. biocon.2004.10.011

Díaz, I. A., Sieving, K. E., Peña-Foxon, M. E., Larraín, J., \& Armesto, J. J. (2010). Epiphyte diversity and biomass loads of canopy emergent trees in Chilean temperate rain forests: a neglected functional component. Forest Ecology and Management, 259, 1490-1501. https://doi.org/10.1016/j.foreco.2010.01.025 .

DiRienzo, J. A., Casanoves, F., Balzarini, M. G., Gonzalez, L., Tablada, M., \& Robledo, C. W. (2011). InfoStat (24th ed.). Córdoba: Universidad Nacional de Córdoba.

Donoso, C., \& Lara, A. (1995). Utilización de los bosques nativos en Chile: pasado, presente y futuro. In J. J. Armesto, C. Villagran, \& M. K. Arroyo (Eds.), Ecología de los Bosques Nativos de Chile (pp. 363-388). Santiago: Editorial Universitaria.

Donoso, P. (2002). Structure and growth in coastal evergreen forests as the bases for uneven-aged structure and growth in coastal evergreen forests as the bases for uneven-aged silviculture in Chile. PhD thesis. Syracuse: SUNY-ESF.

Donoso, P. (2013). Necesidades, opciones y futuro del manejo multietáneo en el centro-sur de Chile. In P. H. Donoso \& Á. B. Promis (Eds.), Silvicultura en Bosques Nativos: Avances en la investigación en Chile, Argentina y Nueva Zelandia (Vol. 1, pp. 55-85, 1). Chile: Marisa Cuneo Eds.

Donoso, P. J. (2005). Crown index: a canopy balance indicator to assess growth and regeneration in uneven-aged forest stands of the Coastal Range of Chile. Forestry, 78, 337-351. https://doi.org/10.1093/forestry/cpi046

Donoso, P. J., \& Donoso, C. (2007). Chile: forest species and stand types. In F. W. Cubbage (Ed.), Forests and Forestry in the Americas: An Encyclopedia. Society of American Foresters and International Society of Tropical Foresters. https://sites. google.com/site/forestryencyclopedia/Home/Chile\%3A\%20Forest\%20Species\% 20and\%20Stand\%20Types. Accessed 2 Feb 2015.

Donoso, P. J., \& Nyland, R. D. (2005). Seedling density according to structure, dominance and understory cover in old-growth forest stands of the evergreen forest type in the coastal range of Chile. Revista Chilena de Historia Natural, 78, 51-63.

Donoso, P. J., Samberg, L., Hernández, M. P., \& Schlegel, B. (2009). The old-growth forests in the Valdivian Andes: composition, structure and growth. In C. Oyarzún, N. Verhoest, P. Boeckx, \& R. Godoy (Eds.), Ecological advances in Chilean temperate rainforests. Ghent: Academia Press.

Doyon, F., Gagnon, D., \& Giroux, J.-F. (2005). Effects of strip and single-tree selection cutting on birds and their habitat in a southwestern Quebec northern hardwood forest. Forest Ecology and Management, 209, 101-116. https://doi.org/10.1016/j.foreco.2005.01.005

Escobar, B., Donoso, C., \& Zúñiga, A. (2006). Capítulo Eucryphia cordifolia. In C. Donoso et al. (Eds.), Especies arbóreas de los bosques templados de Chile y Argentina. Autoecología (pp. 246-255). Marisa Cuneo Eds: Valdivia.

Fuenzalida, H. (1971). Clima: Geografía económica de Chile, texto refundido. Santiago: Corporación de Fomento de la Producción.

Gadow, K. V., Zhang, C. Y., Wehenkel, C., Pommerening, A., Corral-Rivas, J., Korol, M., et al. (2012). Forest structure and diversity. In T. Pukkala \& K. Gadow (Eds.) Continuous cover forestry (Vol. 23, pp. 29-83). Dordrecht: Springer Netherlands.

Gini, C. (1912). Variabilita e mutabilita. Bologna, Tipogr. di P. Cuppini.

Gronewold, C. A., D'Amato, A. W., \& Palik, B. J. (2010). The influence of cutting cycle and stocking level on the structure and composition of 
managed old-growth northern hardwoods. Forest Ecology and Management, 259, 1151-1160. https://doi.org/10.1016/j.foreco.2010.01.001.

Guldin, J. M. (1991). Uneven-aged BDq regulation of Sierra Nevada mixed conifers. Western Journal of Applied Forestry, 6(2), 27-32.

Keeton, W. S. (2006). Managing for late-successional/old-growth characteristics in northern hardwood-conifer forests. Forest Ecology and Management, 235, 129-142. https://doi.org/10.1016/j.foreco.2006.08.005

Kern, C. C., Palik, B. J., \& Strong, T. F. (2006). Ground-layer plant community responses to even-age and uneven-age silvicultural treatments in Wisconsin northern hardwood forests. Forest Ecology and Management, 230, 162-170. https://doi.org/10.1016/j.foreco.2006.03.034

Keyser, T. L., \& Loftis, D. L. (2013). Long-term effects of single-tree selection cutting on structure and composition in upland mixed-hardwood forests of the southern Appalachian Mountains. Forestry, 86, 255-265. https://doi.org/ 10.1093/forestry/cps083.

Kindt, R., \& Coe, R. (2005). Tree diversity analysis: a manual and software for common statistical methods for ecological and biodiversity studies. Nairobi: World Agroforestry Centre (ICRAF).

Kleiber, C., \& Zeileis, A. (2008). Applied econometrics with R (Use R.). New York: Springer.

Lexerød, N. L., \& Eid, T. (2006). An evaluation of different diameter diversity indices based on criteria related to forest management planning. Forest Ecology and Management, 222, 17-28. https://doi.org/10.1016/j.foreco.2005. 10.046 .

Lombardi, F., Marchetti, M., Corona, P., Merlini, P., Chirici, G., Tognetti, R., et al. (2015). Quantifying the effect of sampling plot size on the estimation of structural indicators in old-growth forest stands. Forest Ecology and Management, 346, 89-97. https://doi.org/10.1016/j.foreco.2015.02.011

McElhinny, C., Gibbons, P., Brack, C., \& Bauhus, J. (2005). Forest and woodland stand structural complexity: its definition and measurement. Forest Ecology and Management, 218, 1-24. https://doi.org/10.1016/j.foreco.2005.08.034 .

Moorman, M., Donoso, P. J., Moore, S. E., Sink, S., \& Frederick, D. (2013). Sustainable protected area management: the case of Llancahue, a highly valued periurban forest in Chile. Journal of Sustainable Forestry, 32, 783-805. https://doi.org/10.1080/10549811.2013.803916

Mosseler, A., Lynds, J. A., \& Major, J. E. (2003). Old-growth forests of the Acadian Forest Region. Environmental Reviews, 11, S47-S77. https://doi.org/10.1139/ cjfr-2012-0476

Mueller-Dombois, D., \& Ellenberg, H. (1974). Aims and methods of vegetation ecology. New York: Wiley.

Muñoz, A. A., Chacón, P., Pérez, F., Barnert, E. S., \& Armesto, J. J. (2003). Diversity and host tree preferences of vascular epiphytes and vines in a temperate rainforest in southern Chile. Australian Journal of Botany, 51, 381. https://doi. org/10.1071/BT02070

Myers, N., Mittermeier, R. A., Mittermeier, C. G., da Fonseca, G. A., \& Kent, J. (2000). Biodiversity hotspots for conservation priorities. Nature, 403, 853-858. https:// doi.org/10.1038/35002501 .

Nahuelhual, L., Donoso, P., Lara, A., Núñez, D., Oyarzún, C., \& Neira, E. (2007). Valuing ecosystem services of Chilean temperate rainforests. Environment, Development and Sustainability, 9, 481-499. https://doi.org/10.1007/s10668006-9033-8

Nyland, R. D. (2002). Silviculture. Concepts and applications. Illinois: Wavelan Press, Inc..

O'Hara, K. (2014). Multiaged silviculture: managing for complex forest stands structures. Oxford: Oxford University Press.

O'Hara, K., Hasenauer, H., \& Kindermann, G. (2007). Sustainability in multi-aged stands: an analysis of long-term plenter systems. Forestry, 80, 163-181. https://doi.org/10.1093/forestry/cpl051

Oksanen, J., Blanchet, F. G., Kindt, R., Legendre, P., Minchin, P. R., O'Hara, R. B. et al. (2014). vegan: community ecology package.

Olson, D. M., \& Dinerstein, E. (1998). The global 200: a representation approach to conserving the Earth's most biologically valuable ecoregions. Conservation Biology, 12, 502-515. https://doi.org/10.1046/j. 1523-1739.1998.012003502.x

Oyarzún, C., Nahuelhual, L., \& Núñez, D. (2005). Los servicios ecosistémicos del bosque templado lluvioso: producción de agua y su valoración económica. Revista Ambiente y Desarrollo, 20(3), 88-95.

Paillet, Y., Bergès, L., Hjältén, J., Ódor, P., Avon, C., Römermann, M., et al. (2010). Biodiversity differences between managed and unmanaged forests: metaanalysis of species richness in Europe. Conservation Biology, 24, 101-112. https://doi.org/10.1111/j.1523-1739.2009.01399.x .

Pinheiro, J., Bates, D., DebRoy, S., Sarkar, D., \& R Core Team. (2014). nlme: linear and nonlinear mixed effects models.
Prodan, M., Peters, R., Cox, F., \& Real, P. (1997). Mensura Forestal. San José: Serie Investigación y Educación en Desarrollo Sostenible.

Puettmann, K. J., Wilson, S. M., Baker, S. C., Donoso, P. J., Drössler, L., Amente, G., et al. (2015). Silvicultural alternatives to conventional even-aged forest management-what limits global adoption? Forest Ecosystems, 2, 611. https://doi.org/10.1186/s40663-015-0031-x

Pukkala, T., \& Gadow, K. (Eds.). (2012). Continuous cover forestry (Vol. 23). Dordrecht: Springer Netherlands.

$R$ Core Team. (2015). R: A language and environment for statistical computing. $R$ Foundation for Statistical Computing, Vienna, Austria. https://www.R-project.org/

Rüger, N., Gutiérrez, Á. G., Kissling, W. D., Armesto, J. J., \& Huth, A. (2007). Ecological impacts of different harvesting scenarios for temperate evergreen rain forest in southern Chile - a simulation experiment. Forest Ecology and Management, 252, 52-66. https://doi.org/10.1016/j.foreco.2007.06.020 .

Schütz, J.P., Pukkala, T., Donoso, P. J., \& Gadow, K. V. (2012). Historical emergence and current application of CCF. In T. Pukkala \& K. Gadow (Eds.), Continuous cover forestry (Vol. 23, pp. 1-28). Dordrecht: Springer Netherlands.

Shannon, C. E. (1948). The mathematical theory of communication. In C. E. Shannon \& W. Weaver (Eds.), The mathematical theory of communication (pp. 29-125). Urbana: University of Illinois Press.

Siebert, H. (1998). La silvicultura alternativa: un concepto silvícola para el bosque nativo chileno. In C. Donoso Zegers \& L. Aguilar (Eds.), Silvicultura de los bosques nativos de Chile (pp. 381-407). Santiago: Editorial Universitaria.

Torras, O., Gil-Tena, A., \& Saura, S. (2012). Changes in biodiversity indicators in managed and unmanaged forests in NE Spain. Journal of Forest Research, 17, 19-29. https://doi.org/10.1007/s10310-011-0269-2 .

Torras, O., \& Saura, S. (2008). Effects of silvicultural treatments on forest biodiversity indicators in the Mediterranean. Forest Ecology and Management, 255, 3322-3330. https://doi.org/10.1016/j.foreco.2008.02.013

Wikström, P., \& Eriksson, L. O. (2000). Solving the stand management problem under biodiversity-related considerations. Forest Ecology and Management, 126, 361-376. https://doi.org/10.1016/50378-1127(99)00107-3 .

Zuur, A. F., leno, E. N., Walker, N. J., Saveliev, A. A., \& Smith, G. M. (2009). Mixed effects models and extensions in ecology with R. NY: Springer Science+Business Media.

\section{Submit your manuscript to a SpringerOpen ${ }^{\mathcal{O}}$ journal and benefit from:}

- Convenient online submission

- Rigorous peer review

- Open access: articles freely available online

- High visibility within the field

- Retaining the copyright to your article

Submit your next manuscript at $\boldsymbol{\wedge}$ springeropen.com 